\title{
Developing a Scale of Financial Attitudes in Emergency Fund Ownership Decision Making
}

\author{
Ade Maharini Adiandari 1, *, Bambang Sumintono², and Yuliani ${ }^{3}$ \\ ${ }^{1}$ Department of Management, Faculty of Economics and Business, Ngurah Rai University, \\ Denpasar, Bali, Indonesia \\ ${ }^{2}$ Institute of Educational Leadership, Faculty of Education, Malaya University, Malaya, Malaysia \\ ${ }^{3}$ Department of Management, Faculty of Economics and Business, Sriwijaya University, \\ Palembang, Indonesia \\ Email address: \\ maharini.adiandari@unrac.id (Ade Maharini Adiandari)*,bambang@um.edu.my(Bambang \\ Sumintono),yulianisyapril@unsri.ac.id (Yuliani) \\ ${ }^{*}$ Corresponding authors
}

\begin{abstract}
Financial attitudes in emergency fund ownership decision-making are important in shaping decision-making behavior to have an emergency fund. In order to obtain an accurate profile of financial attitudes in emergency fund ownership decision-making, it required a good instrument with precise measurement model. This study focuses on developing a financial attitude scale in emergency fund ownership decision-making using Rasch model. The participants were 106 respondents and after going through 2 analysis process stages using Winsteps, the instruments possessed a very decent reliability index, both from alpha cronbach's and item reliability value. The items has also met the accuracy of the item model, the unidimensionality number was above the standard, as well as the unexplainable variance by the instruments was not exceed the standard. Overall, it can be concluded that financial attitude scale in emergency fund ownership decision-making held a decent psychometric attitude, so that this attitude scale can be used to a second stage pilot test process with a larger number of respondents.
\end{abstract}

Keywords: Financial Attitude, Emergency Fund, Scale of Emergency Fund Ownership Decision-making, Rasch Model, Winsteps.

\begin{abstract}
Abstrak: Sikap keuangan dalam pengambilan keputusan kepemilikan dana darurat merupakan pendorong terbentuknya perilaku seseorang untuk memiliki dana darurat. Dalam rangka memperoleh gambaran yang akurat tentang sikap keuangan dalam pengambilan keputusan kepemilikan dana darurat, maka diperlukan alat ukur yang berkualitas. Penelitian ini berfokus pada pengembangan skala sikap keuangan dalam pengambilan keputusan kepemilikan dana darurat dengan menggunakan model Rasch. Partisipan penelitian adalah 106 responden dan setelah melalui dua proses tahapan analisis menggunakan Winsteps, instrumen memiliki indeks keandalan yang sangat baik, baik dari nilai alpha cronbach's maupun reliabilitas item. Aitem juga telah memenuhi ketepatan butir model, angka unidimensionalitas berada di atas standar, begitu pula varians yang tidak dapat dijelaskan oleh instrumen tidak melebihi standar. Secara keseluruhan, dapat disimpulkan bahwa skala sikap finansial dalam pengambilan keputusan kepemilikan dana darurat memiliki sifat
\end{abstract}


psikometrik yang baik, sehingga skala sikap ini dapat digunakan untuk proses pilot test tahap kedua dengan jumlah responden yang lebih besar.

Kata Kunci: Sikap keuangan, Dana Darurat, Skala Pengambilan Keputusan Kepemilikan Dana Darurat, Model Rasch, Winsteps.

\section{INTRODUCTION}

The decision-making process of having financial products is included in one of the most important parts of financial planning process, particularly personal financial planning. Personal financial planning is a subject with a wide discussion which requires an integrated overview. (Xiao and Dew, 2011)stated that personal financial planning had to do with the flow of cash, credit, savings and investment management. There were several previous studies which only studied one dimension of financial management attitudes such as credit card (Mien and Thao, 2015); (Nguyen and Quan, 2013) or saving (Gries and Dung, 2014). However, measuring many different domains of financial management attitudes is important because every domain holds a serious role (Xiao and Dew, 2011).

Discussing financial planning has become a more important discussion these past years where in general there have been income improvement, a person's average lifespan improvement, and the development of more increasingly diverse financial instruments and along with more developed innovations in digitalized financial process sector. In addition to that, there has also been a fairly high degree of uncertainty, for instance in terms of inflation to the changes of tax regulations. Before the 1970s, a considerable number of activities associated with relative financial planning were still simple and they were only the necessity of the rich (Ahmed and Salleh, 2016).

Financial Planner Standards Boards define personal financial planning as a process of stipulating on how a person is able to comply life goals through an appropriate financial management. In the study, (Ahmed and Salleh, 2016) adapted the financial planning model (Chieffe and Rakes, 1999) which gave a financial planning framework by paying attention to two things. The first is related to the time identified as the present and the future. The second is related to the financial event predictability as planned and unplanned. Related to this, it can be seen in the financial planning model in Table 1.

Table 1. Financial Planning Model

\begin{tabular}{lcc}
\hline Predictability of Events & Current Period & Future Period \\
\hline Planned Financial Events & Money Management & Investing For Goals \\
& Budgeting & Investment Planning \\
& Income Tax Planning & Retirement Planning \\
Planned Financial Events & Emergency Planning & Transference Planning \\
& Risk Management & Estate Planning
\end{tabular}

Source: Adapted from (Chieffe and Rakes, 1999) p.262 
Taking classifications (Chieffe and Rakes, 1999), then the key elements of financial planning include, 1) money management, a discussion related to the issues of financial management to overcome one's short-term financial issues, 2) emergency planning, a discussion related to the financial issues emerging unexpectedly through the need for emergency funds and insurance, 3 ) investing for goals, a discussion related to investment to accomplish one's medium-term and long-term needs and 4) transference planning, a discussion related to assets transfer planning and other long-term issues including estate planning, business continuation plans, life insurance and various types of trusts for the care of dependents. These key elements are illustrated as a form of financial planning hierarchy as shown in Figure 1.

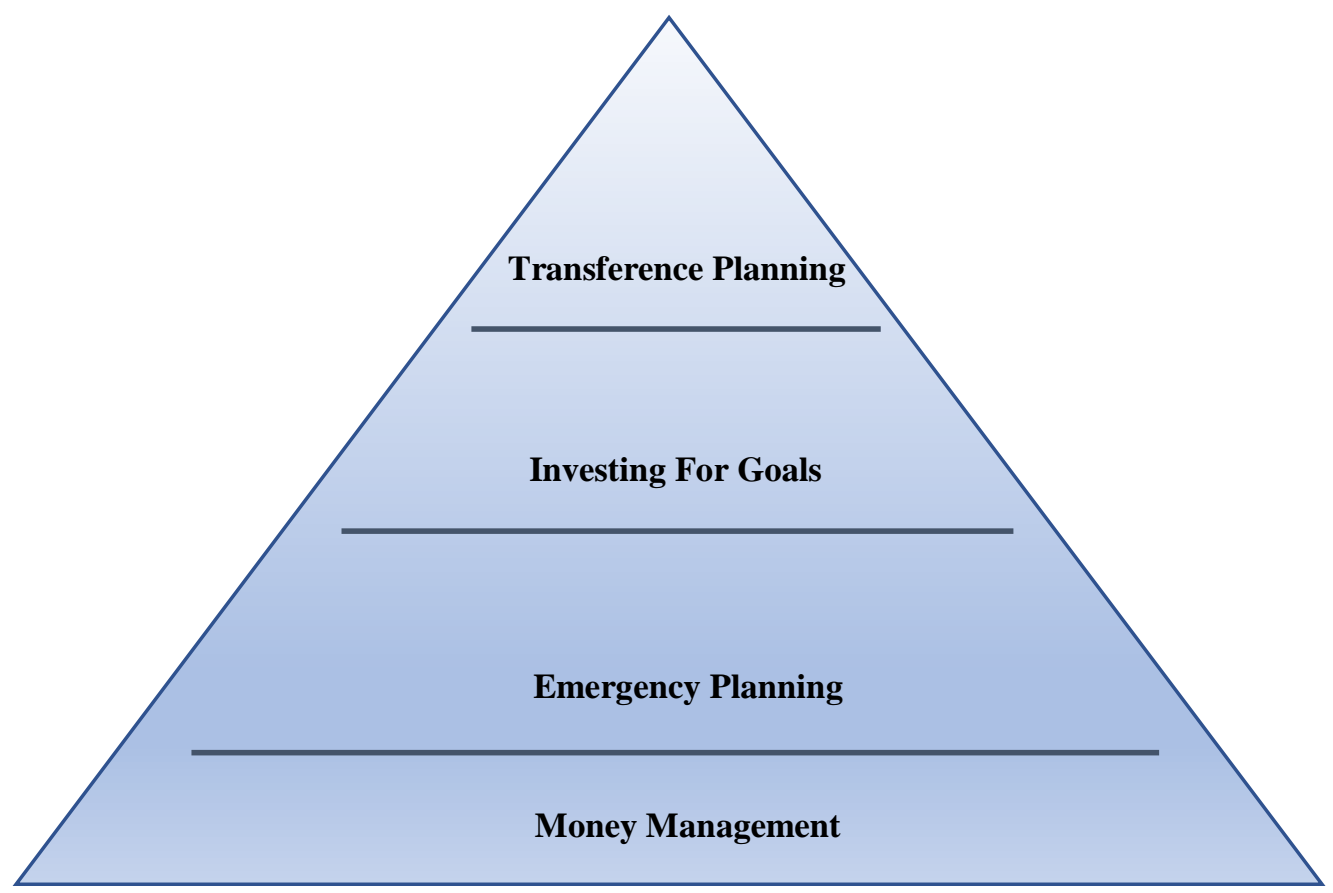

Figure 1. Financial Planning Hierarcy

From Figure 1, it can be explained that the lowest level of financial need must be met before meeting a higher level of financial need. The first stage of money management specifically must be met first, if there are still excess funds, it can be channeled into an emergency fund, investing for goals and transference planning. However, if the household experiences a deficit, it will be less likely to get even an emergency fund placement.

After that, the implementation of personal financial planning as a part of financial planning should be a mandatory thing for everyone, while in fact, not everyone is capable or even wants to do their personal financial planning process. On the other hand, there are many evidences of the risks someone would encounter if they did not do their personal financial planning well, one of which is the situation where young generations are prone to live in a debt circle facilitated by a sumptuous lifestyle and easily attainable credit (Dugas, 2001), the situation where there is a high degree of stressfulness and the decline of psychological well-being degree as the aftermath of the unpreparedness in managing 
psychological costs in relation to high debt (Norvilitis and Santa Maria, 2002). The point is that the failure in managing personal finance can lead to long-term consequences, not only for an individual, but also for a company and society (Munohsamy, 2015). This consequence is even more real in an unfortunate condition, for example this pandemic situation affecting all people in almost all countries in the world in the past one year. There are many challenges encountered in this pandemic situation. Aside from the health issues, this pandemic has also carried a discourse about emergency funds which are extremely important to be prepared in order to deal with the worst scenario. Moreover, the disruption range caused by this pandemic is not known yet.

The low level of awareness of the importance of personal financial planning in Indonesia is supported by the results of National Survey of Financial Literacy or Survei Nasional Literasi Keuangan (SNLIK) from Financial Services Authority or Otoritas Jasa Keuangan $(\mathrm{OJK})$ in relation to financial literacy index and financial inclusion. The data is one of the indicators whether Indonesians have done the financial planning process well. Based on the data from (Otoritas Jasa Keuangan, 2016), the financial literacy index in Indonesia was at $29,7 \%$ in 2016 and increased to $38,03 \%$ in 2019 . While financial inclusion index was at $67,82 \%$ in 2016 and 76,19\% in 2016. This data containing financial literacy and inclusion is definitely expected to experience increases every year so the goal of financial literacy and inclusion strategy which is also the goal of personal financial planning in decreasing poverty rate and increasing Indonesians' well-being can be obtained.

Personal financial planning in this study includes financial planning related to emergency funds, especially one's financial attitude in making decisions on ownership of emergency funds. This research is an early stage research that focuses on developing a scale of financial attitudes in emergency funds ownership decision making. The development aims to obtain quality instruments, moreover that instruments have not been found until now, especially those using the Rasch method.

\section{THEORITICAL REVIEW}

This study focused on the discussion of personal financial planning in emergency planning field, specifically in relation to one's financial attitudes in executing emergency fund decision-making. (Kamarudin et al., 2017) stated that previous studies were not sufficient in defining an emergency fund. (Chase et al., 2011) also stated that researches associated with individual savings tended to emphasize on retirement safety, not for anticipating short-term financial issues which caused researches associated with an emergency fund are still rarely found. This research rarity caused the low level of people's understanding toward an emergency fund. Then this research focused on one's financial attitude perspective. This matter is in accordance to what (Joo and Grable, 2006) stated that complete understanding of emergency fund could be attained if it was studied from attitude perspective.

The presence of an emergency fund functions as a backup fund in facing the risks of one's or family's economy downfall because of Termination of Employment causing unemployment, unanticipated health costs or household expenditures such as houses and vehicles (Babiarz and Robb, 2014). Emergency fund ownership is largely associated with the number of one's liquidity ratio. The more unstable the income and the more difficult to find a job these days, then the larger the liquidity funds needed. The finding of a survey in 
2009 showed that approximately half of Americans sample were unsure of their capability to survive with $\$ 2.000$ within 1 month (Lusardi and Mitchell, 2011). Liquidity risk is a functional tool to study one's emergency fund or what is often called as household emergency funds (Bi and Montalto, 2004). Liquidity ratio, defined as monetary asset ratio toward monthly expenditures, is commonly used in emergency fund researches. Monetary asset is known as liquidity asset including cash (DeVaney, 1995). Then (Kamarudin et al., 2017) stated that there was a tendency of change from year to year toward the classification of emergency fund by the experts. Started from (Johnson and Widdows, 1985) classified three emergency fund indicators based on its liquidity level, including: 1) Monetary emergency funds, are the assets possessed in savings, cheques, and money market accounts; 2) Intermediate emergency funds, are monetary assets plus CDs and saving certificates; 3 ) Comprehensive emergency funds, are intermediate assets plus the value of stocks and bonds. Then (Bi and Montalto, 2004) classified emergency funds include monetary funds, comprehensive and subjective, after that (Bhargava and Lown, 2006) included immediate funds, middle and comprehensive, (Devaney et al., 2007) and (Anong and DeVaney, 2010) were with immediate funds, comprehensive and subjective. For a complete picture, emergency fund classifications from several previous researches are illustrated in table 2.

Table 2. Summary of Example Previous Research on Emergency Fund Classification

\begin{tabular}{|c|c|c|}
\hline $\begin{array}{c}\text { Previous } \\
\text { Studies } \\
\end{array}$ & $\begin{array}{l}\text { Categories of } \\
\text { Fund }\end{array}$ & Elements \\
\hline \multirow[t]{3}{*}{$\begin{array}{c}\text { (Johnson and } \\
\text { Widdows, 1985) } \\
\end{array}$} & Quick fund & $\begin{array}{l}\text { Quick emergency fund, which consists of checking and } \\
\text { savings accounts. }\end{array}$ \\
\hline & Intermediate fund & $\begin{array}{l}\text { Intermediate emergency fund, which consists of the value } \\
\text { of certificates of deposit and }\end{array}$ \\
\hline & $\begin{array}{l}\text { Comprehensive } \\
\text { Fund }\end{array}$ & $\begin{array}{l}\text { Comprehensive emergency fund, which includes the value } \\
\text { of stocks and bonds. }\end{array}$ \\
\hline \multirow[t]{2}{*}{$\begin{array}{l}\text { (Huston and } \\
\text { Chang, 1997) }\end{array}$} & Quick fund & $\begin{array}{l}\text { Assets held in savings, checking and money market } \\
\text { accounts. }\end{array}$ \\
\hline & $\begin{array}{l}\text { Intermediate fund } \\
\text { Comprehensive } \\
\text { Fund }\end{array}$ & $\begin{array}{l}\text { Quick assets, plus CDs and savings certificates. } \\
\text { Intermediate assets, plus the value of stocks } \\
\text { and bonds. }\end{array}$ \\
\hline \multirow[t]{3}{*}{$\begin{array}{c}(\mathrm{Bi} \text { and } \\
\text { Montalto, 2004) }\end{array}$} & Monetary assets & $\begin{array}{l}\text { Monetary assets including assets held in checking, saving, } \\
\text { brokerage accounts and money market funds. }\end{array}$ \\
\hline & $\begin{array}{l}\text { Comprehensive } \\
\text { Assets }\end{array}$ & $\begin{array}{l}\text { Comprehensive assets include monetary assets plus } \\
\text { investment assets held in certificates of deposit, mutual } \\
\text { funds, stocks and bonds. }\end{array}$ \\
\hline & Subjective fund & $\begin{array}{l}\text { Subjective measure of emergency funds based on what } \\
\text { respondents believed were an adequate amount of liquid } \\
\text { assets for them to have available in case of emergencies. }\end{array}$ \\
\hline \multirow[t]{3}{*}{$\begin{array}{l}\text { (Bhargawa and } \\
\text { Lown, 2006) }\end{array}$} & Quick fund & $\begin{array}{l}\text { Quick emergency fund included checking, savings, and } \\
\text { money market accounts. }\end{array}$ \\
\hline & Intermediate Fund & $\begin{array}{l}\text { Intermediate emergency funds included the quick measure } \\
\text { plus certificates of deposit }\end{array}$ \\
\hline & $\begin{array}{l}\text { Comprehensive } \\
\text { Fund }\end{array}$ & $\begin{array}{l}\text { Comprehensive fund included intermediate funds plus } \\
\text { stocks, bonds, and mutual funds. }\end{array}$ \\
\hline \multirow{2}{*}{$\begin{array}{l}\text { (Rodriguez- } \\
\text { Flores and } \\
\text { DeVaney, 2007) }\end{array}$} & Quick fund & $\begin{array}{l}\text { Quick emergency fund includes checking, savings and } \\
\text { money market accounts. }\end{array}$ \\
\hline & Comprehensive Fund & $\begin{array}{l}\text { Comprehensive emergency fund includes the value of } \\
\text { stocks, bonds and mutual funds (but not retirement }\end{array}$ \\
\hline
\end{tabular}




\begin{tabular}{c|c|l}
\hline & Subjective fund & $\begin{array}{l}\text { accounts) with the accounts that are considered as } \\
\text { intermediate emergency fund. }\end{array}$ \\
\cline { 2 - 4 } $\begin{array}{c}\text { (Anong and } \\
\text { DeVaney, 2010) }\end{array}$ & Quick fund & $\begin{array}{l}\text { Subjective measure of emergency fund based on what } \\
\text { respondents believed were an adequate amount of liquid } \\
\text { assets for them to have available in case of emergencies. }\end{array}$ \\
\hline & $\begin{array}{l}\text { Saving and checking accounts, money market accounts and } \\
\text { call accounts. }\end{array}$ \\
\hline & Subjective fund & $\begin{array}{l}\text { Comprehensive fund includes intermediate fund (quick } \\
\text { funds plus certificates of deposit) plus stocks, bonds and } \\
\text { mutual funds that are not held in retirement accounts. }\end{array}$ \\
\hline
\end{tabular}

Source : (Anong and DeVaney, 2010; Bhargava and Lown, 2006; Bi and Montalto, 2004; Johnson and Widdows, 1985; Vodă and Florea, 2019)

From table 2 above, it can be seen that several studies demonstrated the tendency of change toward emergency fund classifications from year to year. If all studies are observed, then emergency classification classifications include Immediate Fund, Middle Fund, Comprehensive Fund and Subjective Fund.

In addition to that, it was also found the standard of the amount of emergency funds possessed by a person from the previous studies, as illustrated in Table 3.

Table 3. Summary of previous research for adequate emergency funds

\begin{tabular}{|c|c|c|c|}
\hline Researchers & Data Set & $\begin{array}{c}\text { Measure of Emergency } \\
\text { Fund }\end{array}$ & $\begin{array}{c}\text { Guideline for adequate } \\
\text { emergency funds }\end{array}$ \\
\hline \multirow[t]{2}{*}{$\begin{array}{c}\text { (Johnson and } \\
\text { Widdows, 1985) }\end{array}$} & \multirow[t]{2}{*}{$\begin{array}{c}1977 \& 1983 \text { Survey of } \\
\text { Consumer Finances } \\
\text { (SCF) }\end{array}$} & Monetary Intermediate & $\begin{array}{l}2 \text { months gross } \\
\text { household income }\end{array}$ \\
\hline & & Comprehensive & $\begin{array}{l}6 \text { months gross } \\
\text { household income }\end{array}$ \\
\hline $\begin{array}{c}\text { (Hanna et al., } \\
1995)\end{array}$ & $\begin{array}{l}\text { 1990-1991 Consumer } \\
\text { Expenditure } \\
\text { Survey } \\
(\text { CES) }\end{array}$ & Liquid assets* & $\begin{array}{l}3 \text { months before-tax } \\
\text { Income }\end{array}$ \\
\hline & & & $\begin{array}{l}3 \text { months take-home } \\
\text { income } \\
3 \text { months spending }\end{array}$ \\
\hline $\begin{array}{l}\text { (Chang and } \\
\text { Huston, 1995) }\end{array}$ & $\begin{array}{c}\text { 1983-1986 panels of } \\
\text { SCF }\end{array}$ & Intermediate & $\begin{array}{l}3 \text { months gross } \\
\text { household income }\end{array}$ \\
\hline (Chang, 1995) & $\begin{array}{l}\text { 1983-1986 panels of } \\
\text { SCF }\end{array}$ & Comprehensive & $\begin{array}{c}3 \text { months gross } \\
\text { household income }\end{array}$ \\
\hline (De Vaney, 1995) & $1977 \& 1989$ SCF & Comprehensive & $\begin{array}{c}3 \text { months gross } \\
\text { household income }\end{array}$ \\
\hline $\begin{array}{c}\text { (Hanna and Wang, } \\
\text { 1995) }\end{array}$ & 1990-1991 CES & Comprehensive & 3 months spending \\
\hline $\begin{array}{c}\text { (Huston and } \\
\text { Chang, 1997) }\end{array}$ & $1992 \mathrm{SCF}$ & $\begin{array}{c}\text { Monetery } \\
\text { Intermediate } \\
\text { Comprehensive }\end{array}$ & $\begin{array}{l}3 \text { months gross } \\
\text { household income }\end{array}$ \\
\hline $\begin{array}{c}\text { (Ding and } \\
\text { DeVaney, 2000) }\end{array}$ & $1998 \mathrm{SCF}$ & $\begin{array}{c}\text { Monetery } \\
\text { Intermediate } \\
\text { Comprehensive }\end{array}$ & $\begin{array}{l}3 \text { months gross } \\
\text { household income }\end{array}$ \\
\hline
\end{tabular}




\begin{tabular}{c|c|c|c}
\hline $\begin{array}{c}\text { (Chen and } \\
\text { DeVaney, 2001) }\end{array}$ & 1998 SCF & $\begin{array}{c}\text { Monetery } \\
\text { Intermediate } \\
\text { Comprehensive }\end{array}$ & $\begin{array}{c}3 \text { months gross } \\
\text { household income }\end{array}$ \\
\hline
\end{tabular}

Source : (Bi and Montalto, 2004)

According to the information contained in Table 3, it is found out that there is no precise universal consensus about the sufficiency standard of individual's or household's emergency funds. According to OJK, emergency funds are ideally 6 to 12 larger than monthly expenditures, depending on dependents and each person's consumption pattern, age, occupation, retirement plan, risk tolerance, and other factors.

Generally, the experts define emergency funds as an available fund ownership which can cover expenditures when emergency situations occur without decreasing the level of comfort drastically. An emergency fund ownership has been trusted to influence individual's and household's life stability and also decrease the level of stressfulness as the result of financial pressure. (Regina Chang and Huston, 1995) stated that income unstability is a real posibility to many people and households in America. That income unstability can be the result of many factors such as switching jobs causing income loss in a short time, salary decreasing, termination of employmet and quitting jobs because of health issues or disabilities (Huston and Chang, 1997).

In the context of financial planning process, holding emergency funds is an essential matter and also to show that an individual or household have executed one of financial planning processes well. For that reason, it is very important to possess positive financial attitudes in emergency fund ownership decision-making, mainly to the individuals who have not understood the importance of this matter for their later lives. It means that financial attitude measuring instruments are needed to make precise decision on emergency fund ownership and to generate accurate data.

In observing the study results by the researchers, the researches focusing on personal financial attitudes are still rarely found, particularly in emergency fund ownership decisionmaking. Financial attitudes by (Furnham, 1984) were explained as the way people spend, save, hoard, and waste money. From the observing results, there were found several instruments, namely financial attitude scale in relation to personal financial management behaviors process (Dowling et al., 2009; Mien and Thao, 2015; Shim et al., 2009). As an example (Mien and Thao, 2015) modified financial attitude scale into 4 constructs, namely attitude toward daily financial behavior, attitude toward saving plan, attitude toward financial management and attitude toward future financial ability with 16 items in total. Those instruments are still being developed by using classical test theory. Until now, there has not been found a development in financial attitude scale in emergency fund ownership decision-making by applying Rasch model approach. Therefore, a research focusing on the development of financial attitude scale in emergency fund ownership decision-making in the process of personal financial planning is needed.

In this study, the author executed the development of financial attitude scale in emergency fund ownership decision-making independently and divided it into several dimensions. Those dimensions included attitude toward financial knowledge about emergency fund and attitude toward planning of emergency fund. The author developed the two dimensions into 5 indicators, including: 1) attitude toward understanding the importance of emergency fund; 2) attitude toward understanding the advantages of emergency fund; 3) attitude toward the accuracy in obtaining emergency fund; 4) attitude 
toward preparing emergency fund and 5) attitude toward stipulating the amount of emergency fund that needs to be prepared. Comparing the developed scales by previous researchers, then the development of scale in this study is expected to be able to enrich and express financial attitudes in emergency fund ownership in the process of personal financial planning in depth.

In accordance to what the author had mentioned above, measurement in the studies of financial attitudes are almost all still developed by using classical test theory approach. Discussing the classical test theory approach, in its development it is explained that there are critics addressed to the classical test theory, one of the critics was by (Mitchell et al., 2002) stating that there was a limitation of analysis tools as the result of the type of data obtained through a measurement questioning attitudes were nominal and ordinal. Critics were also uttered by (Alagumalai et al., 2005) which finally emerged item response theory to fix classical test theory with Rasch model as one of the models of item response theory.

One of the superiorities of Rasch model, compared to classical test theory, is mentioned in a research (Sumintono and Widhiarso, 2014), that is the capability of making predictions toward missing data which can improve the accuracy of model Rasch analysis statistic results. Moreover, the calibrations in modelling Rasch include 3 calibrations, in terms of measurement scale, respondents and items. If a researcher does not calibrate the used research instruments, then it will cause data invalidity and failures in the research which often go unnoticed by the researcher themselves. Results of researches are good quality measuring tools which can be used to obtain accurate information in relation to financial attitudes in emergency fund ownership decision-making in the process of personal financial planning. This is expected to be useful to contribute images of how one's financial attitudes really are toward emergency fund ownership decision-making which eventually can be used by themselves or other people in executing or accompanying financial planning process particularly in terms of emergency fund ownership.

\section{METHODS}

There were many steps in this done in this study, including: first, determining a theoretical construct. The expressed construct is financial attitudes in emergency fund ownership decision-making. Second, identifying and formulating every indicator representing financial attitudes in emergency fund ownership decision-making in the process of personal financial planning. The financial attitudes in emergency fund ownership decision-making scale was developed independently by the author including: 1) attitude toward understanding the importance of emergency fund; 2) attitude toward understanding the advantages of emergency fund; 3) attitude toward the accuracy in obtaining emergency fund; 4) attitude toward preparing emergency fund and 5) attitude toward stipulating the amount of emergency fund that needs to be prepared. The framework of financial attitudes in emergency fund ownership decision-making stipulation in this study is illustrated in Table 4. 
Table 4. Framework Financial Attitudes in Emergency Fund Ownership DecisionMaking Stimulation

\begin{tabular}{cccc}
\hline Aspect/Dimension & Indicator & Item Example & Frequency \\
\hline $\begin{array}{c}\text { Attitude toward } \\
\text { financial } \\
\text { knowledge about } \\
\text { emergency fund }\end{array}$ & $\begin{array}{c}\text { Attitude toward } \\
\text { understanding the importance } \\
\text { of emergency fund } \\
\text { Attitude toward } \\
\text { understanding the advantages } \\
\text { of emergency fund }\end{array}$ & $\begin{array}{c}\text { It is not a problem if I do not have } \\
\text { emergency funds }\end{array}$ & $\begin{array}{c}\text { I believe emergency funds can help } \\
\text { me more relax if there are } \\
\text { unfortunate events }\end{array}$ \\
$\begin{array}{c}\text { Attitude toward } \\
\text { the planning of } \\
\text { emergency fund }\end{array}$ & $\begin{array}{c}\text { Attitude toward the accuracy } \\
\text { in obtaining emergency fund }\end{array}$ & $\begin{array}{c}\text { I believe preparing emergency } \\
\text { funds through cutting unnecessary } \\
\text { expenditures is a proper way }\end{array}$ \\
& $\begin{array}{c}\text { Attitude toward preparing } \\
\text { emergency fund }\end{array}$ & $\begin{array}{c}\text { I believe preparing emergency } \\
\text { funds independently in a form of } \\
\text { short-term savings is the most } \\
\text { proper way }\end{array}$ & 4 \\
& $\begin{array}{c}\text { Attitude toward stipulating } \\
\text { the amount of emergency } \\
\text { fund that needs to be prepared }\end{array}$ & $\begin{array}{c}\text { I believe the capability of saving is } \\
\text { important in preparing emergency } \\
\text { funds }\end{array}$ \\
\hline
\end{tabular}

The number of participants in this study were 106 respondents who came from various heterogeneous individuals, both from a geographical, demographic and socio-economic perspective. Descriptive statistics of respondents can be seen in table 5 .

Table 5. Research Descriptive Statistics

\begin{tabular}{llrr}
\hline No & Remark & Amount & Percentage \\
\hline 1 & Gender & 30 & \\
& Male & 76 & $28,3 \%$ \\
& Female & $\mathbf{1 0 6}$ & $\mathbf{1 0 0 \%}$ \\
& Total & & \\
& & & \\
& Marital Status & 28 & $26 \%$ \\
Not Married & 78 & $74 \%$ \\
Married & $\mathbf{1 0 6}$ & $\mathbf{1 0 0 \%}$ \\
Total & & \\
& & \\
& Occupation & 21 & $19,8 \%$ \\
& Lecturer & 35 & $33,0 \%$ \\
& Employee & 28 & $26,4 \%$ \\
Students & 8 & $7,5 \%$ \\
& Professional & 6 & $5,7 \%$ \\
& Entrepreneur & 8 & $7,5 \%$ \\
& Lainnya & $\mathbf{1 0 0 \%}$ \\
& Total & $\mathbf{1 0 6}$ & \\
& & & \\
& Length of Work & & $38,7 \%$ \\
& $<5$ years & 41 & $21,7 \%$ \\
& 5 until 10 years & 23 & $\mathbf{1 0 0 \%}$
\end{tabular}




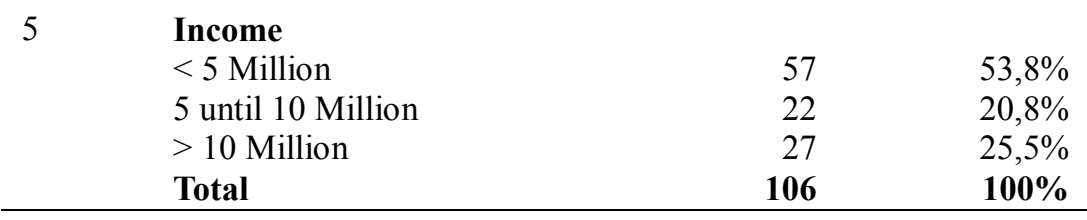

From table 5 above, it is known the diversity of respondents in this study. The diversity of respondents is useful to see the general condition of people's financial attitudes from various aspects, both in terms of gender, marital status, occupation, length of work and income. Moreover, financial planning is actually something that must be done by everyone. For gender, respondents were dominated by female $(71.7 \%)$ than men $(28.3 \%)$. For the marital status, there is a much bigger percentage with married status (74\%) than those with not married status (26\%). Meanwhile, in terms of occupation, the respondents were dominated by three major types of work, namely private employees (33\%), students (26.4\%) and lecturers (19.8\%). From the length of work, it was dominated by employees with length of work $>10$ years $(39.6 \%)$ and under 5 years $(38.7 \%)$, while for income, it was dominated by respondents with income $<5$ million $(53.8 \%)$.

The scaling method used in this scale was summated ratings method (Likert) with 5 response options, namely Completely Agree, Agree, Neutral, Disagree and Completely Disagree. The number of items developed by the author were 20 items in the form of statements. The third step was doing reviews toward the developed items. The developed items were reviewed both from the language side and contents done by 2 (two) professional financial planner practitioners. The result of the reviews showed the compatibility between the developed items and the measurement goals. There was a suggestion from the financial practitioners where for the redactions in item statements were better made in various ways where statements were in the form of positive and negative statements. This was to give adequate time to the respondents in responding the questions, so careless and hasty answers could be avoided. The fourth step was to do a test on the scale reviewed by the assessors. The scaling test was done 2 times which was divided into 2 stages. The scaling test stage 1 was done to 106 respondents then since the results of the scaling test stage 1 was not satisfying, the scaling test stage 2 was planned to be executed to minimum of 250 respondents. This writing contained the results of the scaling test stage 1 . The fifth stage was analyzing the data by using Rasch model approach through Winsteps program. The data analysis included analysis toward items, respondents and count the correlation. In this study, the results of the analysis would be delivered in the form of statistical summaries. The sixth step was finalizing the scale based on the analysis results.

\section{RESULTS}

Based on the analysis results by using Rasch model, the researcher gained information both from the items' side and the respondents. In this study, the data analysis was done 2 times until the items which met the accurate item model or the items that were fit were found. Both of these analysis stages can be seen in Table 6 . 
Table 6. Data Analysis Stages

\begin{tabular}{cccll}
\hline Stage & $\begin{array}{c}\text { Number of } \\
\text { Respondent }\end{array}$ & $\begin{array}{c}\text { Number } \\
\text { of Item }\end{array}$ & \multicolumn{1}{c}{ Result } & \multicolumn{1}{c}{ Follow-up } \\
\hline 1 & 106 & 20 & $\begin{array}{l}\text { 23 respondents } \\
\text { were identified } \\
\text { as outliers and } 3 \\
\text { items were less } \\
\text { precise with the } \\
\text { model }\end{array}$ & $\begin{array}{l}\text { Eliminating respondents } \\
\text { identified as outliers to } \\
\text { check whether there were } \\
\text { still less precise items } \\
\text { with the model and } \\
\text { would do the second data } \\
\text { analysis. }\end{array}$ \\
& & & $\begin{array}{l}\text { All item have } \\
\text { met the accuracy } \\
\text { of the model } \\
\text { grain }\end{array}$ & \\
& 20 & & \\
& & &
\end{tabular}

From table 6 above, there are 2 stages of analysis, where the first stage of the analysis is carried out with 106 respondents and 20 items. The results show that there are 23 respondents who are outliers followed by 3 items that do not fit the model. Furthermore, to further examine the causes for the misfit of the item, it is necessary to carry out a second stage analysis by trying to exclude respondents identified as outliers. The second stage analysis was conducted with 83 respondents while still using 20 items. Furthermore it can be seen that by executing the analysis stages 2 times, then it was gained the result where all items with 20 items in total were finally declared to have met the accuracy of the item model. The summary results of the first stage analysis can be seen in Table 7 .

Table 7. The First Stage Analysis Results Summaries.

\begin{tabular}{|c|c|c|c|}
\hline & Output & Result & Information \\
\hline \multirow[t]{4}{*}{ Instrument } & Alpha Cronbach & 0,85 & measuring the interaction \\
\hline & Unidimensionality & & between person and item \\
\hline & $\begin{array}{l}\text { - Raw variance } \\
\text { explained by measures }\end{array}$ & $27,50 \%$ & $\begin{array}{l}\text { Minimum parameter } \\
20 \%\end{array}$ \\
\hline & $\begin{array}{l}\text { - Unexplained variance } \\
\text { in 1st contrast }\end{array}$ & $10,20 \%$ & parameter $<15 \%$ \\
\hline \multirow[t]{6}{*}{ Item } & Item Reliability & 0,92 & $\begin{array}{l}\text { observing the quality of } \\
\text { items in the instruments }\end{array}$ \\
\hline & Item Separation Value & 3,39 & \\
\hline & $\begin{array}{l}\text { Item Level Separation } \\
(\mathrm{H})\end{array}$ & 4,85 & \\
\hline & Highest Logit Value & $+0,74$ & $\begin{array}{l}\text { The most difficult item } \\
\text { to agree with (N15) }\end{array}$ \\
\hline & Lowest Logit Value & $-1,17$ & $\begin{array}{l}\text { The easiest item to agree } \\
\text { with (N11) }\end{array}$ \\
\hline & $\begin{array}{l}\text { The number of items that } \\
\text { did not meet the } \\
\text { accuracy of item model }\end{array}$ & $3(\mathrm{~N} 4, \mathrm{~N} 3, \mathrm{~N} 19)$ & $\begin{array}{l}\text { parameter using } 0,5< \\
\text { MNSQ }<1,5\end{array}$ \\
\hline \multirow[t]{2}{*}{ Respondent } & Person Reliability & 0,8 & $\begin{array}{l}\text { observing the } \\
\text { consistency of the } \\
\text { respondents' answers }\end{array}$ \\
\hline & Response Separation & 2,03 & \\
\hline
\end{tabular}




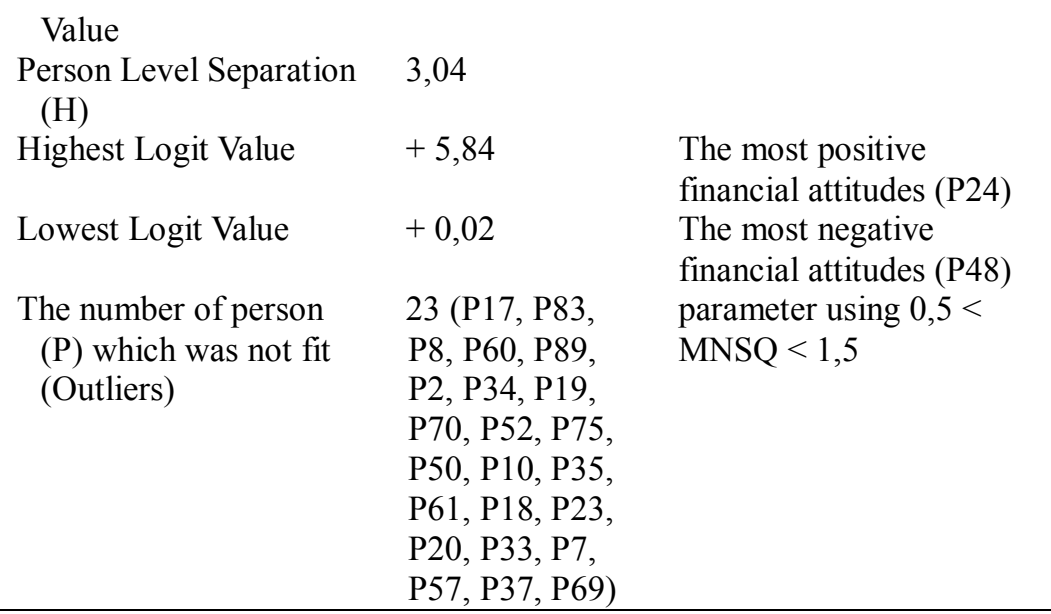

As seen in Table 7 above, it can be seen that there are still items which did not meet the accuracy of item model from the first stage analysis, therefore the researcher executed the second stage analysis. The second stage analysis was conducted based on follow-up information of the data analysis of the first stage where the researcher would do an elimination of respondents who were identified as outliers. This was done to do a further check whether after the elimination of respondents who were identified as outliers, then the items could accomplish the conditions of the accuracy of item model. The summary results of the second stage analysis can be seen in Table 8 .

Table 8. The Second Stage Analysis Results Summaries

\begin{tabular}{|c|c|c|c|}
\hline & Output & Result & Information \\
\hline \multirow[t]{3}{*}{ Instrument } & $\begin{array}{l}\text { Alpha Cronbach } \\
\text { Unidimensionality }\end{array}$ & 0,89 & $\begin{array}{l}\text { measuring the interaction } \\
\text { between person and item }\end{array}$ \\
\hline & $\begin{array}{l}\text { - Raw variance explained } \\
\text { by measures }\end{array}$ & $33,10 \%$ & Minimum parameter $20 \%$ \\
\hline & $\begin{array}{l}\text { - Unexplained variance } \\
\text { in } 1 \text { st contrast }\end{array}$ & $10,70 \%$ & parameter $<15 \%$ \\
\hline \multirow[t]{6}{*}{ Item } & Item Reliability & 0,93 & $\begin{array}{l}\text { observing the quality of } \\
\text { items in the instruments }\end{array}$ \\
\hline & Item Separation Value & 3,74 & \\
\hline & $\begin{array}{l}\text { Item Level Separation } \\
(\mathrm{H})\end{array}$ & 5,32 & \\
\hline & Highest Logit Value & $+0,96$ & $\begin{array}{l}\text { The most difficult item to } \\
\text { agree with (N15) }\end{array}$ \\
\hline & Lowest Logit Value & $-1,53$ & $\begin{array}{l}\text { The easiest item to agree } \\
\text { with (N11) }\end{array}$ \\
\hline & $\begin{array}{l}\text { The number of items that } \\
\text { did not meet the accuracy } \\
\text { of item model }\end{array}$ & - & $\begin{array}{l}\text { parameter using } 0,5< \\
\text { MNSQ }<1,5\end{array}$ \\
\hline \multirow[t]{2}{*}{ Respondent } & Person Reliability & 0,85 & $\begin{array}{l}\text { observing the consistency } \\
\text { of the respondents' } \\
\text { answers }\end{array}$ \\
\hline & $\begin{array}{l}\text { Response Separation } \\
\text { Value }\end{array}$ & 2,43 & \\
\hline
\end{tabular}




$\begin{array}{ll}\begin{array}{l}\text { Person Level Separation } \\ (\mathrm{H})\end{array} & 3,57 \\ \text { Highest Logit Value } & +6,87 \\ \text { Lowest Logit Value } & +0,12 \\ & \\ \text { The number of person } & 8 \\ \text { (P) which was not fit } & \\ \text { (Outliers) } & \end{array}$

The most positive financial attitudes (P24)

The most negative financial attitudes (P48)

parameter using $0,5<$ MNSQ $<1,5$

From Table 8 above, it can be seen that in general, these items can ultimately meet the requirements for the accuracy of the model items. This can be seen from the results where all items meet the accuracy of the model items using the parameter $0.5<\mathrm{MNSQ}<1.5$. For more details, table 9 shows the results of the first stage analysis regarding the Misfit Item and table 10 shows the results of the analysis related to the second stage regarding to item fit order.

Table 9. Misfit Order Item in first stage analysis

\begin{tabular}{|c|c|c|c|c|c|c|c|c|c|c|c|c|c|c|}
\hline \multirow{2}{*}{$\begin{array}{c}\text { ENTRY } \\
\text { NUM- } \\
\text { BER }\end{array}$} & \multirow{2}{*}{$\begin{array}{l}\text { TO-TAL } \\
\text { SCORE }\end{array}$} & \multirow{2}{*}{$\begin{array}{l}\text { TOTAL } \\
\text { COUNT }\end{array}$} & \multirow{2}{*}{$\begin{array}{l}\text { MEA- } \\
\text { SURE }\end{array}$} & \multirow{2}{*}{$\begin{array}{l}\text { MODEL } \\
\text { S.E. }\end{array}$} & \multicolumn{2}{|c|}{ INFIT } & \multicolumn{2}{|c|}{ OUTFIT } & \multicolumn{3}{|c|}{ PT-MEASURE } & \multirow{2}{*}{$\begin{array}{l}\text { EXACT } \\
\text { OBS\% }\end{array}$} & \multirow{2}{*}{$\begin{array}{c}\text { МАТСН } \\
\text { ЕХР\% }\end{array}$} & \multirow{2}{*}{ Item } \\
\hline & & & & & MNSQ & ZSTD & MNSQ & ZSTD & & $\mathrm{RR}$ & EXP. & & & \\
\hline 4 & 446 & 106 & 0.00 & 0.13 & 1.33 & 1.8 & 2.76 & 6.7 & A & 0.28 & 0.45 & 54.1 & 52.3 & $\mathrm{~N} 4$ \\
\hline 3 & 487 & 106 & -0.93 & 0.18 & 1.55 & 2.6 & 2.09 & 3.8 & B & 0.23 & 0.34 & 59.2 & 61.4 & N3 \\
\hline 19 & 395 & 106 & 0.72 & 0.11 & 1.35 & 2.3 & 1.86 & 4.6 & $\mathrm{C}$ & 0.42 & 0.54 & 45.9 & 42.9 & N19 \\
\hline 1 & 452 & 106 & -0.10 & 0.14 & 1.36 & 1.9 & 1.29 & 1.5 & $\mathrm{D}$ & 0.43 & 0.44 & 52 & 52.7 & N1 \\
\hline 20 & 422 & 106 & 0.38 & 0.12 & 1.26 & 1.6 & 1.29 & 1.6 & $\mathrm{E}$ & 0.45 & 0.49 & 39.8 & 47.6 & $\mathrm{~N} 20$ \\
\hline 6 & 471 & 106 & -0.50 & 0.15 & 1.14 & 0.8 & 1.1 & 0.5 & $\mathrm{~F}$ & 0.4 & 0.39 & 56.1 & 55.8 & N6 \\
\hline 13 & 441 & 106 & 0.09 & 0.13 & 1.07 & 0.5 & 1.13 & 0.8 & G & 0.44 & 0.46 & 62.2 & 51.7 & N13 \\
\hline 15 & 393 & 106 & 0.74 & 0.11 & 1.04 & 0.3 & 1.13 & 0.9 & $\mathrm{H}$ & 0.51 & 0.54 & 42.9 & 42.4 & N15 \\
\hline 8 & 418 & 106 & 0.43 & 0.12 & 1.12 & 0.8 & 1.11 & 0.7 & I & 0.51 & 0.50 & 49 & 46.9 & N8 \\
\hline 16 & 440 & 106 & 0.10 & 0.13 & 0.75 & -1.6 & 1.07 & 0.5 & $\mathrm{~J}$ & 0.47 & 0.46 & 60.2 & 51.7 & N16 \\
\hline 2 & 441 & 106 & 0.09 & 0.13 & 1.07 & 0.5 & 1.03 & 0.2 & $\mathrm{j}$ & 0.5 & 0.46 & 58.2 & 51.7 & $\mathrm{~N} 2$ \\
\hline 5 & 468 & 106 & -0.43 & 0.15 & 0.98 & 0 & 0.89 & -0.5 & $\mathrm{i}$ & 0.47 & 0.40 & 60.2 & 54.5 & N5 \\
\hline 11 & 494 & 106 & -1.17 & 0.19 & 0.68 & -1.9 & 0.96 & -0.1 & $\mathrm{~h}$ & 0.37 & 0.31 & 75.5 & 65.6 & N11 \\
\hline 10 & 415 & 106 & 0.47 & 0.12 & 0.93 & -0.4 & 0.95 & -0.2 & $\mathrm{~g}$ & 0.53 & 0.51 & 45.9 & 46.8 & N10 \\
\hline 17 & 440 & 106 & 0.10 & 0.13 & 0.93 & -0.3 & 0.92 & -0.4 & $\mathrm{f}$ & 0.5 & 0.46 & 57.1 & 51.7 & N17 \\
\hline 12 & 430 & 106 & 0.26 & 0.12 & 0.92 & -0.5 & 0.93 & -0.4 & $\mathrm{e}$ & 0.52 & 0.48 & 39.8 & 50.2 & N12 \\
\hline 18 & 448 & 106 & -0.03 & 0.13 & 0.9 & -0.5 & 0.9 & -0.5 & $\mathrm{~d}$ & 0.49 & 0.44 & 58.2 & 52.3 & N18 \\
\hline 7 & 480 & 106 & -0.73 & 0.17 & 0.76 & -1.4 & 0.78 & -1.1 & $\mathrm{c}$ & 0.43 & 0.36 & 68.4 & 58.3 & N7 \\
\hline 9 & 443 & 106 & 0.05 & 0.13 & 0.63 & -2.4 & 0.65 & -2.2 & $\mathrm{~b}$ & 0.55 & 0.46 & 66.3 & 52.2 & N9 \\
\hline 14 & 415 & 106 & 0.47 & 0.12 & 0.59 & -3.2 & 0.64 & -2.4 & $\mathrm{a}$ & 0.61 & 0.51 & 57.1 & 46.8 & N14 \\
\hline MEAN & 442.0 & 106.0 & 0.0 & 0.1 & 1.0 & 0.0 & 1.2 & 0.7 & & & & 55.4 & 51.8 & \\
\hline S.D. & 27.4 & 0.0 & 0.5 & 0.0 & 0.3 & 1.5 & 0.5 & 2.1 & & & & 9.2 & 5.5 & \\
\hline
\end{tabular}


Table 9 above shows the results of the first stage analysis regarding misfit items using parameters $0.5<\mathrm{MNSQ}<1.5$. Three items were identified that were not quite right with the model, namely Items N4, N3 and N19. Based on the results in table 9, a second stage analysis was carried out using 83 respondents and the results of the order fit item in the second stage analysis are shown in table 10.

Table 10. Item Fit Order in second stage analysis

\begin{tabular}{|c|c|c|c|c|c|c|c|c|c|c|c|c|c|c|}
\hline \multirow{2}{*}{$\begin{array}{c}\text { ENTRY } \\
\text { NUMBER }\end{array}$} & \multirow{2}{*}{$\begin{array}{l}\text { TOTAL } \\
\text { SCORE }\end{array}$} & \multirow{2}{*}{$\begin{array}{l}\text { TOTAL } \\
\text { COUNT }\end{array}$} & \multirow{2}{*}{$\begin{array}{l}\text { MEA- } \\
\text { SURE }\end{array}$} & \multirow{2}{*}{$\begin{array}{c}\text { MODEL } \\
\text { S.E. }\end{array}$} & \multicolumn{2}{|c|}{ INFIT } & \multicolumn{2}{|c|}{ OUTFIT } & \multicolumn{3}{|c|}{ PT-MEASURE } & \multirow{2}{*}{$\begin{array}{c}\text { EXACT } \\
\text { OBS\% }\end{array}$} & \multirow{2}{*}{$\begin{array}{c}\text { МАТСН } \\
\text { ЕХР\% }\end{array}$} & \multirow[b]{2}{*}{ Item } \\
\hline & & & & & MNSQ & ZSTD & MNSQ & ZSTD & & RR. & EXP. & & & \\
\hline 20 & 323 & 83 & 0.56 & 0.15 & 1.39 & 2.1 & 1.48 & 2.4 & A & 0.48 & 0.58 & 42.7 & 51.7 & $\mathrm{~N} 20$ \\
\hline 1 & 356 & 83 & -0.35 & 0.18 & 1.45 & 2.2 & 1.25 & 1.2 & $\mathrm{~B}$ & 0.48 & 0.49 & 57.3 & 59.1 & N1 \\
\hline 6 & 366 & 83 & -0.7 & 0.19 & 1.4 & 2.0 & 1.37 & 1.6 & $\mathrm{C}$ & 0.41 & 0.45 & 50.7 & 59.7 & N6 \\
\hline 8 & 326 & 83 & 0.49 & 0.15 & 1.28 & 1.6 & 1.26 & 1.4 & $\mathrm{D}$ & 0.56 & 0.57 & 53.3 & 51.9 & N8 \\
\hline 19 & 305 & 83 & 0.96 & 0.14 & 1.14 & 0.9 & 1.27 & 1.5 & $\mathrm{E}$ & 0.55 & 0.61 & 53.3 & 45.8 & N19 \\
\hline 16 & 337 & 83 & 0.22 & 0.16 & 0.85 & -0.8 & 1.27 & 1.3 & $\mathrm{~F}$ & 0.51 & 0.54 & 62.7 & 57.4 & N16 \\
\hline 5 & 358 & 83 & -0.42 & 0.18 & 1.18 & 1.0 & 1.13 & 0.7 & G & 0.5 & 0.48 & 60 & 60 & N5 \\
\hline 2 & 339 & 83 & 0.16 & 0.16 & 1.09 & 0.5 & 1.08 & 0.5 & $\mathrm{H}$ & 0.56 & 0.54 & 64 & 57.6 & N2 \\
\hline 4 & 352 & 83 & -0.22 & 0.18 & 1.03 & 0.2 & 1.08 & 0.5 & I & 0.48 & 0.5 & 61.3 & 59 & N4 \\
\hline 15 & 305 & 83 & 0.96 & 0.14 & 1.04 & 0.3 & 1.07 & 0.5 & $\mathbf{J}$ & 0.58 & 0.61 & 42.7 & 45.8 & N15 \\
\hline 12 & 322 & 83 & 0.59 & 0.15 & 1.05 & 0.3 & 1.02 & 0.2 & $\mathrm{j}$ & 0.59 & 0.58 & 41.3 & 50.8 & N12 \\
\hline 10 & 316 & 83 & 0.72 & 0.15 & 0.97 & -0.1 & 1 & 0.1 & $\mathrm{i}$ & 0.6 & 0.59 & 45.3 & 48.5 & N10 \\
\hline 17 & 339 & 83 & 0.16 & 0.16 & 0.93 & -0.3 & 0.86 & -0.7 & $\mathrm{~h}$ & 0.57 & 0.54 & 62.7 & 57.6 & N17 \\
\hline 13 & 344 & 83 & 0.02 & 0.17 & 0.87 & -0.6 & 0.84 & -0.8 & $\mathrm{~g}$ & 0.54 & 0.53 & 65.3 & 58.3 & N13 \\
\hline 9 & 337 & 83 & 0.22 & 0.16 & 0.82 & -1.0 & 0.86 & -0.7 & f & 0.58 & 0.54 & 62.7 & 57.4 & N9 \\
\hline 3 & 385 & 83 & -1.53 & 0.23 & 0.84 & -0.9 & 0.8 & -0.7 & $\mathrm{e}$ & 0.38 & 0.36 & 61.3 & 65 & N3 \\
\hline 18 & 347 & 83 & -0.07 & 0.17 & 0.8 & -1.1 & 0.75 & -1.3 & $\mathrm{~d}$ & 0.58 & 0.52 & 62.7 & 58.3 & N18 \\
\hline 7 & 374 & 83 & -1.02 & 0.21 & 0.78 & -1.3 & 0.76 & -1.0 & $\mathrm{c}$ & 0.49 & 0.42 & 68 & 61.6 & N7 \\
\hline 11 & 382 & 83 & -1.38 & 0.22 & 0.72 & -1.7 & 0.74 & -1.0 & b & 0.45 & 0.38 & 70.7 & 62.8 & N11 \\
\hline 14 & 320 & 83 & 0.63 & 0.15 & 0.63 & -2.5 & 0.71 & -1.8 & $\mathrm{a}$ & 0.67 & 0.58 & 58.7 & 50.6 & N14 \\
\hline MEAN & 341.7 & 83 & 0 & 0.17 & 1.01 & 0 & 1.03 & 0.2 & & & & 57.3 & 55.9 & \\
\hline S.D. & 23 & 0 & 0.7 & 0.02 & 0.23 & 1.3 & 0.23 & 1.1 & & & & 8.5 & 5.4 & \\
\hline
\end{tabular}

Table 10 above shows the results of the second stage analysis related to items fit order using the parameter $0.5<$ MNSQ $<1.5$. There were no identified items that did not fit the model.

Furthermore, to confirm the results of this study, an analysis of the validity of the ranking scale was also carried out. It aims to find out whether the choice of rating scale used is confusing for respondents or not. This is important to do considering the results of the first stage analysis identified 23 respondents who were misfit and feared to be the cause of items that did not meet the model requirements. To see the results of the validity of the ranking scale, the Andrich Threshold can be used which is carried out in both stages of data 
analysis, both in the first stage of analysis and the second stage of analysis. The results of the Andrich Threshold measurement can be seen in Table 11.

Table 11. Rating Scale

\begin{tabular}{ccc}
\hline \multirow{2}{*}{ Category Label } & \multicolumn{2}{c}{ Andrich Threshold } \\
& First Stage & Second Stage \\
\hline 1 & None & None \\
2 & -88 & $-2,15$ \\
3 & -43 & $-0,29$ \\
4 & -23 & $-0,05$ \\
5 & 1,54 & 2,48 \\
\hline
\end{tabular}

From table 11 above, it can be seen that the results of the validity of the ranking scale using the Andrich Threshold in both stages of the analysis show that the value moves from None to negative and continues to lead to positive. This shows that the rating scale given is valid for the respondent.

\section{DISCUSSION}

From the research results that have been described above, it can be discussed that at the initial stage of analysis with 106 respondents, the result of item reliability test on financial attitude instruments was at 0,92, while the person reliability was at 0,80 . This matter showed that actually the quality of the items in the instrument was very decent and the consistency of the respondents' answers was fairly good. The value of Alpha Cronbach was 0,85 , this matter showed the overall interaction between the person and the item which was also decent. Next, from the initial stage of analysis, misfit results were identified, especially on the respondent's side with a total of 23 respondents. This resulted in 3 items that did not meet the accuracy of the model items. Respondents of 23 respondents identified as outliers.

According to (Boone, Yale, \& Staver, 2014), the parameter that can be used to find out the presence of items that did not meet the accuracy of item model and the number of outlier respondents among others: 1) Outfit mean square value (MNSQ) accepted : 0,5 < MNSQ < 1,5, 2) outfit Z-Standard value (ZSTD) accepted : $-2,0<$ ZSTD $<+2,0$ and 3) point measure correlation value (Pt Mean Corr) : 0,4 < Pt Measure Corr $<0,85$. The comparison of the different results between the item reliability test and the person misfit order, raises the suspicion that there are respondents who are still confused in responding to statements from items. It is feared that the result of the person misfit is one of the causes of the 3 items that are declared not meeting the accuracy of the model items. For this reason, a second stage analysis was carried out by excluding respondents who were declared as outliers in the results of the first stage analysis.

The second stage analysis was done with 83 respondents, the item reliability test on financial attitude instruments was 0,93 , while the person reliability person was 0,85 . It showed that the quality of the items in the instrument was very decent and the consistency of the respondents' answers was good. The value of Alpha Cronbach was 0,89, it showed that the overall interaction between the person and the item was very decent. If compared 
to the data analysis results of the first stage, then the data analysis results of the second stage was better, which can be seen in the higher number of the item and person reliability and also the value of Alpha Cronbach. Further from this second stage analysis, all items were declared to meet the conditions of the accuracy of item model by using the same parameter as the parameter used in the first stage data analysis.

Furthermore, to support the results of the above analysis and in accordance with the data analysis process, the researcher conducted a rating scale analysis which aimed to verify whether the respondents were confused about the ranking of choices used by the researcher in this study. The comparison of the results of the rating scale analysis in the first and second stage data analysis can be seen in table 11. In this study, five of likert rating scale (strongly disagree, disagree, neutral, agree and strongly agree) is included in the politomical data. According to (Sumintono and Widhiarso, 2014), the recommended measurement level scale testing can use the Andrich Threshold. This test is to test whether the politomic value used is correct or not. The results of the rating scale calculation in table 11, both in the first and second stage of the analysis process, generally show that the Andrich Threshold value that moves from NONE then is negative and continues to lead to positive sequentially, indicating that the options given are valid for respondents. From the results of Andrich Threshold, it can also be seen that the results in the second stage data analysis showed an increased number compared to the first stage data analysis.

The results of the study also showed that all respondents filled all items completely. Another important result of the analysis was measuring tool unidimensionality which functions to find out instruments' capability in measuring what should be measured. It is important to know that the instrument being developed can actually produce information that focuses on the attributes being measured. According to (Sumintono and Widhiarso, 2014), the minimum requirement of unidimensionality is $20 \%$ and unexplainable variance by instruments is not more than $15 \%$. If seen from the first and second stage analysis summaries, each unidimensionality number was above $20 \%$, where successively at $27,5 \%$ and $33,10 \%$ and so was with the unexplainable variance by instruments is not more than $15 \%$ successively at $10,20 \%$ and $10,70 \%$. This shows that the instruments developed related to the scale of financial attitudes in making decisions on emergency fund ownership have been able to measure what should be measured.

Further, according to the data analysis process, the researcher did rating scale analysis aiming to verify whether the respondents experienced confusion on preferred rating used by the researcher in this study. The comparison of rating scale analysis results on the first and second stage data analysis can be seen in table 8 .

\section{CONCLUSION}

Based on the analysis results using Rasch model, financial attitude scale in emergency fund ownership decision-making was proven to contribute consistent results. After undergoing two analysis process stages, 20 items proposed initially could meet the conditions of the accuracy of item model. Instrument coefficient reliability 0,89 , item reliability 0,93 and person reliability 0,85 . It showed that the interaction between the person and the item was very decent, item quality was very decent and the consistency of the respondents' answers were good. The five alternative answers, completely disagree, disagree, neutral, agree, and completely agree) also did not confuse the respondents. 
Therefore, overall, financial attitude scale in emergency fund ownership decision-making was proven to have a good psychometric property and can be used for further studies in the form of second stage scaling test with a larger number of respondents.

\section{REFERENCES}

Ahmed, H., and Salleh, A. M. H. A. P. M. (2016). International Journal of Islamic and Middle Eastern Finance and Management. Managerial Finance, 34(10). https://doi.org/10.1108/mf.2008.00934jaa.001.

Alagumalai, S., Cu rtis, D. D., and Hungi, N. (2005). Applied Rasch Measurement : a Book of Exemplars Education in the Asia- Pacific Region : Issues , Concerns and Prospects, 353.

Anong, S. T., and DeVaney, S. A. (2010). Determinants of adequate emergency funds including the effects of seeking professional advice and industry affiliation. Family and Consumer Sciences Research Journal, 38(4), 405-419. https://doi.org/10.1111/j.1552-3934.2010.00035.x.

Babiarz, P., and Robb, C. A. (2014). Financial Literacy and Emergency Saving. Journal of Family and Economic Issues, 35(1), 40-50. https://doi.org/10.1007/s10834-0139369-9.

Bhargava, V., and Lown, J. M. (2006). Preparedness for financial emergencies: Evidence from the survey of consumer finances. Journal of Financial Counseling and Planning, $17(2), 17-26$.

Bi, L., and Montalto, C. (2004). Emergency Funds and Alternative Forms of Saving. Financial Services Review, 13(2), 93.

Boone, W. J., Yale, M. S., and Staver, J. R. (2014). Rasch analysis in the human sciences. Rasch Analysis in the Human Sciences. https://doi.org/10.1007/978-94-007-6857-4.

Chase, S., Gjertson, L., and Collins, J. M. (2011). Coming Up with Cash in a Pinch: Emergency Savings and Its Alternatives. Center for Financial Security, (June), 1-41. Retrieved from http://cfs.wisc.edu/News_Releases/Coming_Up_with_Cash_in_a_Pinch_Emergency _Savings_and_Its_Alternatives.pdf.

Chieffe, N., and Rakes, G. K. (1999). FSR_1999_An integrated model for financial planning.pdf, 8, 261-268.

DeVaney. (1995). Emergency fund adequacy among U.S. households in 1977 and 1989. Consumer Interests Annual, 222-223.

Devaney, S. A., Anong, S. T., and Whirl, S. E. (2007). Household savings motives. Journal of Consumer Affairs, 4l(1), 174-186. https://doi.org/10.1111/j.17456606.2006.00073.x.

Dowling, N. A., Corney, T., and Hoiles, L. (2009). Financial management practices and money attitudes as determinants of financial problems and dissatisfaction in young male australian workers. Journal of Financial Counseling and Planning, 20(2), 5-13.

Dugas, C. (2001). Debt smothers young Americans, 5.

Furnham, A. (1984). Many sides of the coin: The psychology of money usage. Personality and Individual Differences, 5(5), 501-509. https://doi.org/10.1016/01918869(84)90025-4.

Gries, T., and Dung, H. Van. (2014). Household Savings and Productive Capital Formation 
in Rural Vietnam: Insurance vs. Social Network. Modern Economy, 05(08), 878-894. https://doi.org/10.4236/me.2014.58081.

Huston, S. J., and Chang, Y. R. (1997). Adequate emergency fund holdings and household type. Journal of Financial Counseling and Planning, 8(1), 37-46.

Johnson, D., and Widdows, R. (1985). Emergency fund levels of households. The Proceedings of the American Council on Consumer Interests 31 th Annual Conference.

Joo, S.-H., and Grable, J. (2006). Using Predicted Perceived Emergency Fund Adequacy to Segment Prospective Financial Consulting Clients. Financial Services Review, 15(4), 297.

Kamarudin, N., Dzolkarnaini, N., Rasedee, A., and FL, M. I. (2017). Does Emergency Fund Provision Is Just About Saving? : A Conceptual Paper. International Journal of Arts and Humanities, 3(4), 38-42.

Lusardi, A., and Mitchell, O. (2011). Financial Literacy Around The World - Annamaria Lusardi and Olivia S. Mitchell. Nber, 17(4), 1-14.

Mien, N. T. N., and Thao, T. P. (2015). Factors Affecting Personal Financial Management Behaviors: Evidence from Vietnam. Proceedings of the Second Asia-Pacific Conference on Global Business, Economics, Finance and Social Sciences (AP15Vietnam Conference) ISBN: 978-1-63415-833-6 Danang-Vietnam, 10-12 July, 2015 Paper ID: VL532, 63415. Retrieved from http://globalbizresearch.org/Vietnam_Conference/pdf/VL532.pdf.

Mitchell, R. K., Busenitz, L., Lant, T., McDougall, P. P., Morse, E. A., and Smith, J. B. (2002). Toward a Theory of Entrepreneurial Cognition: Rethinking the People Side of Entrepreneurship Research. Entrepreneurship Theory and Practice , 27(2), 93-104. https://doi.org/10.1111/1540-8520.00001.

Munohsamy, T. (2015). Personal Financial Management, (June).

Nguyen, P. D., and Quan, V. D. H. (2013). Factors Affecting to Card Payment's Choice: An Empirical Study of HCM City, Vietnam. SSRN Electronic Journal. https://doi.org/10.2139/ssrn.2364239.

Norvilitis, J. M., and Santa Maria, P. (2002). Credit card debt on college campuses : Causes , consequences , and solutions. College Student Journal, 36(3), 356.

Otoritas Jasa Keuangan. (2016). Survei Nasional Literasi dan Inklusi Keuangan 2016 (National Literacy and Financial Inclusion Survey 2016). Survey Report, 1-26. Retrieved from www.ojk.go.id.

Regina Chang, Y., and Huston, S. J. (1995). Patterns of adequate household emergency fund holdings: A comparison of households in 1983 and 1986. Journal of Financial Counseling and Planning, 6, 119-128.

Shim, S., Xiao, J. J., Barber, B. L., and Lyons, A. C. (2009). Pathways to life success: A conceptual model of financial well-being for young adults. Journal of Applied $\begin{array}{lll}\text { Developmental } & \text { Psychology, } & \text { 30(6), }\end{array}$ https://doi.org/10.1016/j.appdev.2009.02.003

Sumintono, B., and Widhiarso, W. (2014). Model Rasch untuk Penelitian Aplikasi, (SEPTEMBER 2013).

Vodă, A., and Florea, N. (2019). Impact of Personality Traits and Entrepreneurship Education on Entrepreneurial Intentions of Business and Engineering Students. Sustainability (Vol. 11). https://doi.org/10.3390/su11041192.

Xiao, J. J., and Dew, J. (2011). The Financial Management Behavior Scale: Development 
and Validation. Journal of Financial Counseling and Planning, 22(1), 43-59. Retrieved from https://digitalcommons.uri.edu/cgi/viewcontent.cgi?referer=https://www.google.com /\&httpsredir=1\&article=1001\&context=hdf_facpubs. 